\title{
Potassium Silicate, Against Water Stress, in Sweet Corn Plant Growth Traits
}

\author{
Ausbie Luis Graça Araújo ${ }^{1}$, Amanda Maria de Almeida ${ }^{2}$, João de Jesus Guimarães ${ }^{2}$, \\ Fernando Soares de Cantuário ${ }^{3}$, Leandro Caixeta Salomão ${ }^{3}$, Carmen Rosa da Silva Curvêlo ${ }^{3}$, \\ Aurelio Rúbio Neto ${ }^{1}$, José Magno Queiroz $\mathrm{Luz}^{4} \&$ Alexandre Igor Azevedo Pereira ${ }^{3}$ \\ ${ }^{1}$ Instituto Federal Goiano, Campus Rio Verde, Rio Verde, Goiás, Brazil \\ ${ }^{2}$ Universidade Estadual Paulista Júlio de Mesquita Filho, Botucatu, São Paulo, Brazil \\ ${ }^{3}$ Instituto Federal Goiano, Campus Urutaí, Urutaí, Goiás, Brazil \\ ${ }^{4}$ Universidade Federal de Uberlândia, Campus Umuarama, Uberlândia, Minas Gerais, Brazil \\ Correspondence: Alexandre Igor Azevedo Pereira, Instituto Federal Goiano, Campus Urutaí, Rodovia Geraldo \\ Silva Nascimento, Km 2.5, Fazenda Palmital, CEP: 75.790-000, Urutaí, Goiás, Brazil. Tel: 55-649-9287-4821. \\ E-mail: aiapereira@yahoo.com.br
}

Received: November 7, 2018

Accepted: February 4, $2019 \quad$ Online Published: April 15, 2019

doi:10.5539/jas.v11n5p172

URL: https://doi.org/10.5539/jas.v11n5p172

\begin{abstract}
Water stress in sweet corn plants due effect of climatic events, such as El Niño, is difficult to monitor, leading to considerable losses. Silicon ( $\mathrm{Si}$ ) as an exogenous resistance elicitor may reduce water stress effects. The relationship between sweet corn plant age and its development, under induced water stress and leaf potassium silicate applications were evaluated. This work was carried out with the hybrid Tropical Plus ${ }^{\circledR}$, in a randomized factorial block design with $15,30,45$ and $60 \mathrm{kPa}$ as soil water tensions in plots and potassium silicate doses $(0,6$, 12 and $24 \mathrm{~L} \mathrm{ha}^{-1}$ ) in subplots. Stem diameter, plant height and leaf number per plant were evaluated at 30, 45, 60, 75 and 90 days after seeding. Root length was measured on the $90^{\text {th }}$ day after seeding. Sweet corn plants submitted to water stress conditions and $\mathrm{Si}$ application showed an age-dependent response. Water stress did not decrease stem diameter, plant height and number of leaves per plant sprayed with $\mathrm{Si}$. Root length was longer with $60 \mathrm{kPa}$ soil water tension. Silicon reduced negative impacts of water stress on sweet corn plants.
\end{abstract}

Keywords: Poaceae, silicon, soil-water tension, Zea mays

\section{Introduction}

Water stress is a limiting factor in agriculture, reducing plant development and yield. The need to maintain plant quality in water scarcity condition, a common situation in the Brazilian Cerrado Savanna (Heinemann et al., 2009), is one of the main agricultural challenges in Brazil. The climatic events, such as El Niño (Li et al., 2011), reduce precipitation, even during the rainy season, leading to plant water stress (Doto et al., 2015).

Sweet corn cultivation has expanded, mainly in the Brazilian Midwest, with the largest area cultivated in this country for canned fresh sweet corn agroindustries increasing jobs and income of small and medium-sized farmers. Sweet corn cultivated in the Goiás state (Salton et al., 2014) is used for produce spikes (with high added value) and fodder for cattle. Additionally, straw can be incorporated into the soil for no-tillage in crops like soybean, bean and cotton. The company Syngenta Seeds Ltda dominates the sweet corn seed market in Brazil, with the Tropical Plus ${ }^{\mathbb{B}}$ hybrid.

Silicate fertilization is a promising technology because silicon ( $\mathrm{Si}$ ) is an elicitor inducing plant resistance to abiotic stresses (Zhu \& Gong, 2014). Si accumulation in transpiration organs influences the formation of a silica double layer which reduces stomata opening, leaf transpiration and water losses (Guntzer et al., 2012). Exogenous Si sources help to maintain the integrity and stability of the plant cell membrane under biotic or abiotic stress (Maghsoudi et al., 2016) as a resistance elicitor in biochemical plant processes, including oxidative stress from stress conditions (Malčovská et al., 2014).

Corn plant responses to exogenous $\mathrm{Si}$ source applications is due to accumulation of this element associated with aerobic respiration (Nissan et al., 2015). The genes ZmLsil and ZmLsi6 are responsible for Si mechanism 
transport from the soil solution to the root cells and from the xylem to the rest of the plant, respectively (Mitani et al., 2009).

The beneficial Si effects on corn plants in tropical agriculture need to be further studied because Brazilian soils, especially those in the Cerrado Savanna biome, are poor in soluble Si (Camargo et al., 2013). Fertilizers with Si can stimulate sweet corn plant resistance to water stress. Water soluble potassium silicate $\left(\mathrm{K}_{2} \mathrm{SiO}_{3}\right)$ is one of the most readily available commercial $\mathrm{Si}$ sources easily applied as a foliar fertilizer in fertigation or hydroponic culture.

Zea mays L. (Poaceae) tolerates water scarcity during its vegetative stage but suffers high impacts during its reproductive stage (Barnaby et al., 2013). Technologies and practices to reduce the effects of water stress in economically and socially important crops should be evaluated. In this way, the objective was to examine if leaf spraying with potassium silicate $\left(6,12\right.$ and $\left.24 \mathrm{~L} \mathrm{ha}^{-1}\right)$ can reduce the negative effects of water stress, assessing different soil-water tensions on the sweet corn, Tropical Plus ${ }^{\circledR}$ hybrid, development traits. Sweet corn response was analyzed using an age-dependent analysis performed at 30, 45, 60, 75 and 90 days after seeding.

\section{Methods}

The sweet corn plants were cultivated in a simple arc type greenhouse ( $30 \mathrm{~m}$ long, $7 \mathrm{~m}$ wide and $6.2 \mathrm{~m}$ arc height) with East-West orientation, constructed with a metallic structure, covered with low-density polyethylene (LDPE) film $(0.15 \mathrm{~mm}$ thick) and its sides with anti-aphid mesh. The climate of the region is classified as tropical altitude $(\mathrm{Cwb})$ with dry winters and rainy summers by Köppen.

The Conservas Oderich SA company (Orizona, Goiás state, Brazil) supplied the sweet corn seeds of Tropical Plus ${ }^{\circledR}$ hybrid (Syngenta Seeds Ltda) and the technical management information for this crop. Sowing was performed in April, 2015 with $80 \times 25 \mathrm{~cm}$ spacing with three seeds at $2 \mathrm{~cm}$ deep pit. Fertilization was performed via fertigation (Trani et al., 2011) and the water distribution was evaluated shortly after the irrigation system installation (Borssoi et al., 2012). The water distribution uniformity was $97 \%$.

The experimental design had a randomized complete block design, with subplots, in a $4 \times 4$ factorial design with four soil-water tensions $(15,30,45$ and $60 \mathrm{kPa})$ and four potassium silicate concentrations $(0,6,12$ and $24 \mathrm{~L}$ of $\mathrm{K}_{2} \mathrm{SiO}_{3} \mathrm{ha}^{-1}$ ), 16 treatments and four replications. The experiment had four useful plots (blocks) with two parallel planting lines per plot except for the borderlines, at the lateral ends of the greenhouse, which had one planting line. An irrigation lateral line with one dripping tube with auto-compensated driplines spaced $0.3 \mathrm{~m}$, totaling eight useful lateral lines plus two located in the margins, were used per planting line. Soil was plowed with a 14 HP mini tractor, model TC14 of (Yanmar Agritech ${ }^{\circledR}$ ) with rotary hoe. The $1.0 \mathrm{~m}$ wide beds were, manually constructed, spaced at $7.0 \mathrm{~m}$ between them totaling 16 beds in the experiment.

Each planting line had a of $16 \mathrm{~mm}$ diameter lateral irrigation line with outlets spaced every $0.30 \mathrm{~m}$ in the drip irrigation scheme. The outflow was $1.4 \mathrm{~L} \mathrm{~h}^{-1}$ with a $1 \mathrm{kgf} \mathrm{cm}^{2}$ pressure service. The pumping system had a $1 \mathrm{HP}$ pump motor. The fertilizer was injected with a suction system of the pump driven by a valve set to control the flow. A blind of 120 mesch, in addition to valves and manometers to gauge the force per unit area of the irrigation scheme, was installed shortly after the pumping system.

The irrigation was managed with tensiometry using soil water retention curves (Tahir et al., 2012) and adjusted by a model (Van Guenuchten, 1980) with the Soil Water Retention Curve software (SWRC, version 3.0) (Dourado Neto et al., 2000). Two puncture tensiometers at 0.20 and $0.40 \mathrm{~m}$ deep, at each experimental plot (totaling 32 tensiometers), were installed to monitor the soil water tensions measured with a digital tensiometer, SondaTerra ${ }^{\circledR}$ model (Piracicaba, São Paulo state, Brazil).

The irrigation management was similar in the first 30 days after sweet corn seeding, to assure plant establishment. Irrigations were similar for all plots with permanent soil moisture control near field capacity. A $20.0 \mathrm{~mm}$ level was applied in the first two days after planting and bear $2.0 \mathrm{~mm}$ in the remaining days, according to the water retention curve to keep the soil near a $-10 \mathrm{kPa}$ matric potential.

Potassium silicate was sprayed in the subplots with a $20.0 \mathrm{~L}$ hand-operated costal spray. Drift protection was adapted to reduce water losses and contamination to adjacent subplots without potassium silicate. Four applications were performed. Cultural treatments, such as leaving one plant per pit were made and invasive ones were manually removed. Phytosanitary control was carried out preventively throughout the experiment.

Stem diameter $(\mathrm{mm})$, plant height $(\mathrm{cm})$ and number of leaves per sweet corn plant were quantified at 30, 45, 60, 75 and 90 days after seeding (DAS). The length $(\mathrm{cm})$ of the longest vertical root (root length) of sweet corn plants was measured shortly after harvesting $\left(90^{\text {th }}\right.$ day after seeding), through destructive plant analyses with cutting the shoot at $10.0 \mathrm{~cm}$ cut the soil. The roots were washed in running water and the soil at their base 
removed to evaluate the bare roots. A total of 16 whole roots per plant were removed from the soil per subplot. Roots broken during their removal were discarded.

Data were submitted to the premises of variance analysis (ANOVA). Normality was verified by the Lilliefors adherence test and by the proportion of the histogram obtained by the SAEG ${ }^{\circledR}$ software (Ribeiro Junior \& Melo, 2009). The four dependent variables followed normal distribution and, consequently, their means were presented without transformation. Data were analyzed with ANOVA, through a $4 \times 4$ factorial arrangement, in randomized block design, considering soil-water tension as level A in the plots and potassium silicate doses as level B in the subplots. The factor $\mathrm{B} / \mathrm{a}_{\mathrm{i}}$ was tested by the mean square and the number of degrees of freedom of the residue (b) of significant interactions and the $\mathrm{A} / \mathrm{b}_{\mathrm{j}}$ factor levels with the mean square and the number of degrees of freedom of the mean residue (combined). The A factor levels were tested with the mean square and the number of degrees of freedom of the residue (a) of the non-significant interactions, and those of B factor with the mean square and the number of degrees of freedom of the residue (b).

The age-dependent development analysis, considering the effect of the independent variables (soil-water tensions and potassium silicate doses) within each time interval (30, 45, 60, 75 and 90 DAS) was performed by with the data of each soil-water tension (Figures 1, 2 and 3). The dependent variables, over time, were analyzed by regression analyzes considering potassium silicate doses. The results of the ANOVA under factorial design were described, while the data corresponding to the regression analyzes in the figure legends. The second form represented (Figures 4A, 4B and 4C) considered the averages of all sweet corn development parameters evaluations, excluding the evaluation through time. This data treatment is a general effect of soil-water tensions and potassium silicate doses with the regression analyzes for the dependent variables as a function of soil-water tensions performed. The potassium silicate doses were again plotted to build regression curves. The ANOVA results under factorial arrangement were described, whereas the data corresponding to the regression analyzes put in the legends.

The root length variable data, evaluated only on the $90^{\text {th }}$ day after seeding, was submitted to an ANOVA under factorial design. The time intervals were not considered because root length assessment was performed at the end of the plant cycle. The mean tests were performed with Tukey test at 5\% probability level, after verifying the significance (or not) of the interacting factors, isolated, through ANOVA with factorial arrangement. Statistical analysis (ANOVA) were performed using the SAEG ${ }^{\circledR}$ software, and figures with SigmaPlot ${ }^{\circledR}$ software version 11 (Systat Software Inc).

\section{Results}

The two independent factors, soil-water tensions and potassium silicate doses, affected the sweet corn stem diameter responses at $30(\mathrm{~F}=12.98, \mathrm{df}=36, \mathrm{P}=0.04), 45(\mathrm{~F}=33.56, \mathrm{df}=36, \mathrm{P}=0.01), 60(\mathrm{~F}=15.54, \mathrm{df}=36$, $\mathrm{P}=0.02), 75(\mathrm{~F}=22.10, \mathrm{df}=36, \mathrm{P}=0.001)$ and $90(\mathrm{~F}=40.14, \mathrm{df}=36, \mathrm{P}=0.03)$ days after seeding (Figure 1$)$. This response showed a cubic regression model without differences between treatments at $15 \mathrm{kPa}$ soil-water tension for each day after seeding evaluation (Figure 1A). Potassium silicate doses began to interact with soil-water tensions from $30 \mathrm{kPa}$ up (Figure 1B), $40 \mathrm{kPa}$ (Figure 1C) to $60 \mathrm{kPa}$ soil-water tension (Figure 1D) for all five days after seeding evaluation. The applications of potassium silicate were determinant to maintain higher values of stem diameter as soil-water tension increased. Stem diameter of sweet corn plants had the highest fluctuation as showed by seeding observed data, according to plant height and number of leaves per plant. 

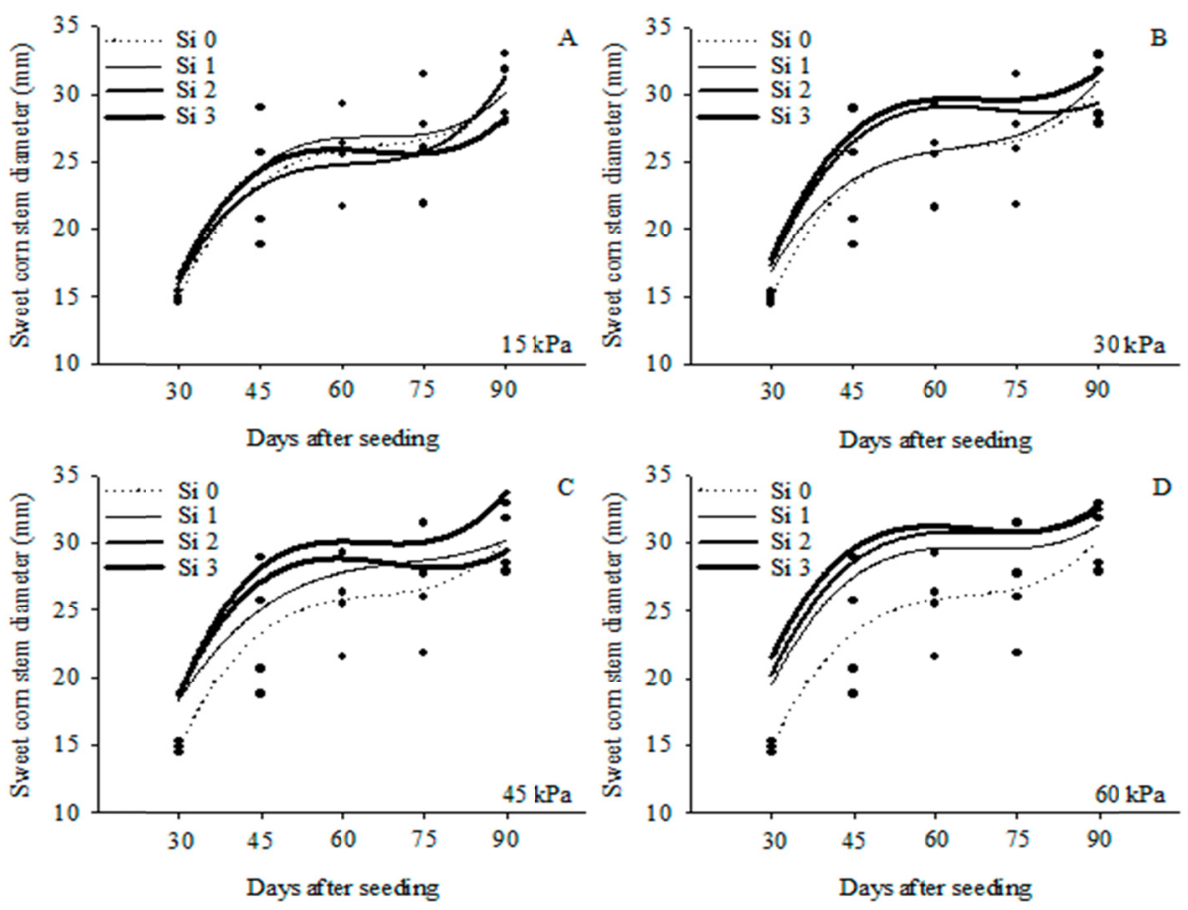

Figure 1. Regression analysis for stem diameter (mm) of sweet corn plants (Zea mays L.) Tropical Plus ${ }^{\circledR}$ hybrid, at five time intervals after germination with different soil water tensions and potassium silicate doses. $\mathrm{Si} 0(0 \mathrm{~L}$ of $\left.\mathrm{K}_{2} \mathrm{SiO}_{3} \mathrm{ha}^{-1}\right)$, Si $1\left(6 \mathrm{~L}_{\text {of }} \mathrm{K}_{2} \mathrm{SiO}_{3} \mathrm{ha}^{-1}\right)$, Si $2\left(12 \mathrm{~L}_{\text {of }} \mathrm{K}_{2} \mathrm{SiO}_{3}\right.$ ha $\left.^{-1}\right)$ and $\mathrm{Si} 3\left(24 \mathrm{~L}_{\text {of }} \mathrm{K}_{2} \mathrm{SiO}_{3} \mathrm{ha}^{-1}\right)$. IF Goiano, Urutaí campus, Goiás state, Brazil

Note. Regression data for stem diameter at $15 \mathrm{kPa}$ : Si $0\left(\mathrm{y}=-38.34+2.87 \mathrm{x}-0.04 \mathrm{x}^{2}+0.0002 \mathrm{x}^{3}, \mathrm{R}^{2}=0.87, \mathrm{~F}=\right.$ 17.74, $P=0.01)$, Si $1\left(\mathrm{y}=-40.97+3.07 \mathrm{x}-0.04 \mathrm{x}^{2}+0.0002 \mathrm{x}^{3}, \mathrm{R}^{2}=0.97, \mathrm{~F}=108.96, P=0.01\right)$, Si $2(\mathrm{y}=-36.15$ $\left.+2.91 \mathrm{x}-0.04 \mathrm{x}^{2}+0.0003 \mathrm{x}^{3}, \mathrm{R}^{2}=0.94, \mathrm{~F}=47.26, P=0.01\right)$ and Si $3\left(\mathrm{y}=-38.17+2.98 \mathrm{x}-0.04 \mathrm{x}^{2}+0.0002 \mathrm{x}^{3}\right.$, $\left.\mathrm{R}^{2}=0.94, \mathrm{~F}=47.06, P=0.01\right)$.

Regression data for stem diameter at $30 \mathrm{kPa}$ : Si $0\left(\mathrm{y}=-39.91+3.10 \mathrm{x}-0.04 \mathrm{x}^{2}+0.0002 \mathrm{x}^{3}, \mathrm{R}^{2}=0.93, \mathrm{~F}=40.34\right.$, $P=0.01), \mathrm{Si} 1\left(\mathrm{y}=-26.26+2.34 \mathrm{x}-0.03 \mathrm{x}^{2}+0.0002 \mathrm{x}^{3}, \mathrm{R}^{2}=0.95, \mathrm{~F}=60.47, P=0.01\right), \mathrm{Si} 2(\mathrm{y}=-36.41+2.83 \mathrm{x}$ $\left.-0.04 \mathrm{x}^{2}+0.0002 \mathrm{x}^{3}, \mathrm{R}^{2}=0.97, \mathrm{~F}=92.85, P=0.01\right)$ and $\mathrm{Si} 3\left(\mathrm{y}=-40.41+3.11 \mathrm{x}-0.04 \mathrm{x}^{2}+0.0002 \mathrm{x}^{3}, \mathrm{R}^{2}=0.97\right.$, $\mathrm{F}=90.17, P=0.01$ ).

Regression data for stem diameter at $45 \mathrm{kPa}$ : Si $0\left(\mathrm{y}=-35.80+2.89 \mathrm{x}-0.04 \mathrm{x}^{2}+0.0002 \mathrm{x}^{3}, \mathrm{R}^{2}=0.97, \mathrm{~F}=86.49\right.$, $P=0.01)$, Si $1\left(\mathrm{y}=-17.30+1.83 \mathrm{x}-0.02 \mathrm{x}^{2}+0.0001 \mathrm{x}^{3}, \mathrm{R}^{2}=0.95, \mathrm{~F}=55.63, P=0.01\right)$, Si $2(\mathrm{y}=-45.54+3.52 \mathrm{x}$ $\left.-0.05 \mathrm{x}^{2}+0.0003 \mathrm{x}^{3}, \mathrm{R}^{2}=0.93, \mathrm{~F}=34.57, P=0.01\right)$ and $\mathrm{Si} 3\left(\mathrm{y}=-33.98+2.85 \mathrm{x}-0.04 \mathrm{x}^{2}+0.0002 \mathrm{x}^{3}, \mathrm{R}^{2}=0.97\right.$, $\mathrm{F}=92.92, P=0.01$ ).

Regression data for stem diameter at $60 \mathrm{kPa}$ : Si $0\left(\mathrm{y}=-31.67+2.71 \mathrm{x}-0.03 \mathrm{x}^{2}+0.0002 \mathrm{x}^{3}, \mathrm{R}^{2}=0.95, \mathrm{~F}=51.21\right.$, $P=0.01)$, Si $1\left(\mathrm{y}=-29.38+2.61 \mathrm{x}-0.03 \mathrm{x}^{2}+0.0002 \mathrm{x}^{3}, \mathrm{R}^{2}=0.87, \mathrm{~F}=16.90, P=0.01\right)$, Si $2(\mathrm{y}=-31.73+2.79 \mathrm{x}$ $\left.-0.04 \mathrm{x}^{2}+0.0002 \mathrm{x}^{3}, \mathrm{R}^{2}=0.97, \mathrm{~F}=111.81, P=0.01\right)$ and Si $3\left(\mathrm{y}=-29.75+2.77 \mathrm{x}-0.04 \mathrm{x}^{2}+0.0002 \mathrm{x}^{3}, \mathrm{R}^{2}=\right.$ $0.96, \mathrm{~F}=78.15, P=0.01)$.

The plant height (Figure 2) and number of leaves per plant (Figure 3) had similar means between treatments and time interval evaluated. The soil-water tensions and potassium silicate doses, isolated or in interaction, were not significant. Cubic regression curves were the best fit for plant height and number of leaves per plant responses (Figures 2 and 3). 

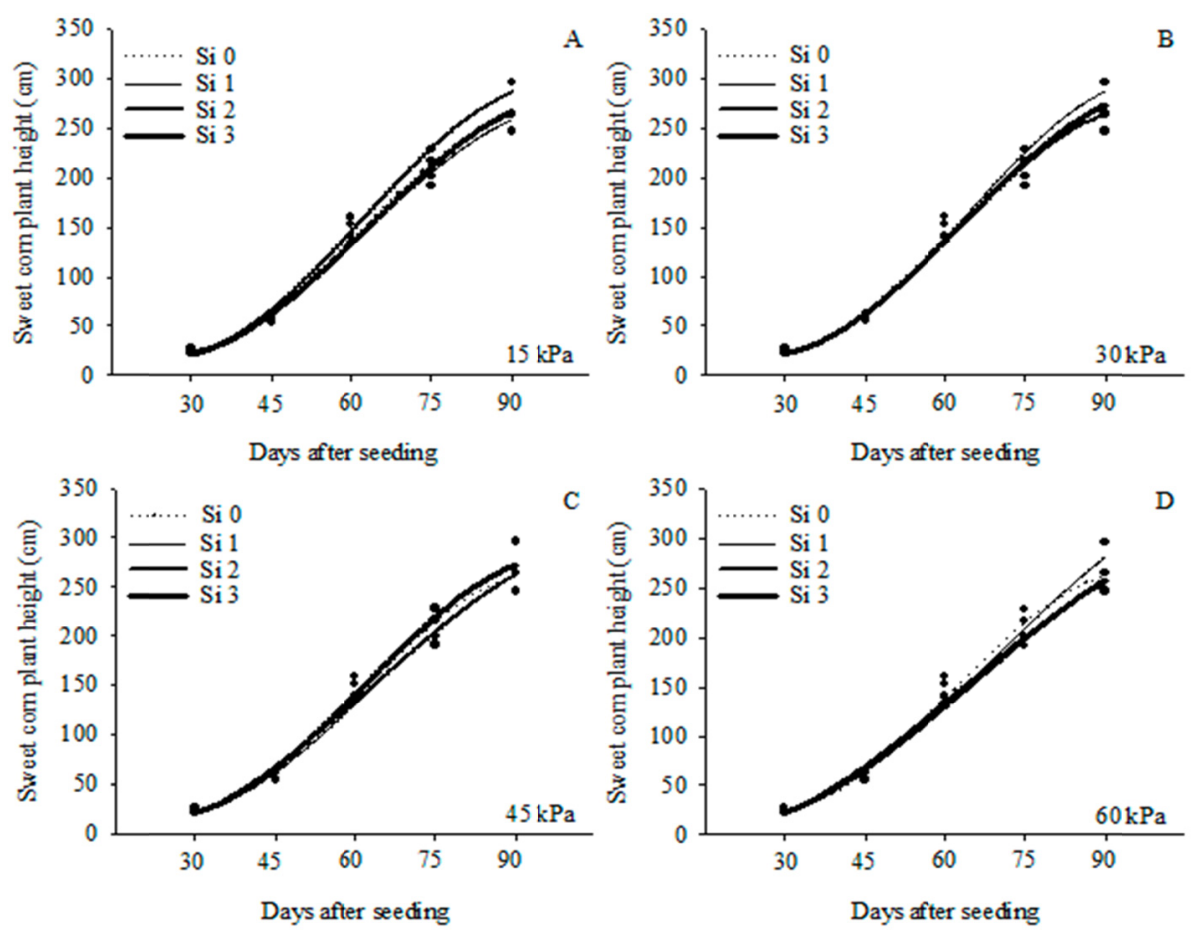

Figure 2. Regression analysis of plant height $(\mathrm{cm})$ of sweet corn plants (Zea mays L.), Tropical Plus ${ }^{\circledR}$ hybrid, at five time intervals after germination and submitted to different soil water tensions with potassium silicate doses. Si $0\left(0 \mathrm{~L}_{\text {of }} \mathrm{K}_{2} \mathrm{SiO}_{3} \mathrm{ha}^{-1}\right)$, Si $1\left(6 \mathrm{~L}_{\text {of }} \mathrm{K}_{2} \mathrm{SiO}_{3} \mathrm{ha}^{-1}\right)$, Si $2\left(12 \mathrm{~L}_{\text {of }} \mathrm{K}_{2} \mathrm{SiO}_{3} h^{-1}\right)$ and $\mathrm{Si} 3\left(24 \mathrm{~L}_{\text {of }} \mathrm{K}_{2} \mathrm{SiO}_{3} \mathrm{ha}^{-1}\right)$. IF Goiano, Urutaí campus, Goiás state, Brazil

Note. Regression data for plant height at $15 \mathrm{kPa}$ : Si $0\left(\mathrm{y}=168.47-12.43 \mathrm{x}+0.28 \mathrm{x}^{2}-0.0016 \mathrm{x}^{3}, \mathrm{R}^{2}=0.98, \mathrm{~F}=\right.$ 246.69, $P=0.01)$, Si $1\left(\mathrm{y}=102.76-7.85 \mathrm{x}+0.20 \mathrm{x}^{2}-0.0011 \mathrm{x}^{3}, \mathrm{R}^{2}=0.99, \mathrm{~F}=365.00, P=0.01\right)$, Si $2(\mathrm{y}=$ $\left.171.43-12.28 \mathrm{x}+0.29 \mathrm{x}^{2}-0.0016 \mathrm{x}^{3}, \mathrm{R}^{2}=0.99, \mathrm{~F}=772.06, P=0.01\right)$ and $\operatorname{Si} 3\left(\mathrm{y}=138.15-10.00 \mathrm{x}+0.24 \mathrm{x}^{2}-\right.$ $\left.0.0013 \mathrm{x}^{3}, \mathrm{R}^{2}=0.98, \mathrm{~F}=141.36, P=0.01\right)$.

Regression data for plant height at $30 \mathrm{kPa}$ : Si $0\left(\mathrm{y}=102.40-8.22 \mathrm{x}+0.22 \mathrm{x}^{2}-0.0012 \mathrm{x}^{3}, \mathrm{R}^{2}=0.98, \mathrm{~F}=234.34\right.$, $P=0.01)$, Si $1\left(\mathrm{y}=212.67-14.34 \mathrm{x}+0.31 \mathrm{x}^{2}-0.0017 \mathrm{x}^{3}, \mathrm{R}^{2}=0.98, \mathrm{~F}=181.00, P=0.01\right), \mathrm{Si} 2(\mathrm{y}=170.65-$ $\left.12.04 \mathrm{x}+0.28 \mathrm{x}^{2}-0.0015 \mathrm{x}^{3}, \mathrm{R}^{2}=0.98, \mathrm{~F}=133.76, P=0.01\right)$ and $\mathrm{Si} 3\left(\mathrm{y}=152.45-10.85 \mathrm{x}+0.25 \mathrm{x}^{2}-0.0014 \mathrm{x}^{3}\right.$, $\left.\mathrm{R}^{2}=0.97, \mathrm{~F}=116.68, P=0.01\right)$.

Regression data for plant height at $45 \mathrm{kPa}$ : Si $0\left(\mathrm{y}=182.44-12.41 \mathrm{x}+0.28 \mathrm{x}^{2}-0.0015 \mathrm{x}^{3}, \mathrm{R}^{2}=0.98, \mathrm{~F}=185.43\right.$, $P=0.01)$, Si $1\left(\mathrm{y}=116.21-8.71 \mathrm{x}+0.21 \mathrm{x}^{2}-0.0012 \mathrm{x}^{3}, \mathrm{R}^{2}=0.99, \mathrm{~F}=282.51, P=0.01\right), \operatorname{Si} 2(\mathrm{y}=32.50-3.85 \mathrm{x}$ $\left.+0.13 \mathrm{x}^{2}-0.0007 \mathrm{x}^{3}, \mathrm{R}^{2}=0.98, \mathrm{~F}=159.27, P=0.01\right)$ and $\mathrm{Si} 3\left(\mathrm{y}=141.71-10.49 \mathrm{x}+0.25 \mathrm{x}^{2}-0.0014 \mathrm{x}^{3}, \mathrm{R}^{2}=\right.$ $0.98, \mathrm{~F}=168.88, P=0.01$ ).

Regression data for plant height at $60 \mathrm{kPa}$ : Si $0\left(\mathrm{y}=8.08-1.65 \mathrm{x}+0.07 \mathrm{x}^{2}-0.0003 \mathrm{x}^{3}, \mathrm{R}^{2}=0.97, \mathrm{~F}=106.27, P=\right.$ $0.01)$, Si $1\left(\mathrm{y}=78.27-5.93 \mathrm{x}+0.15 \mathrm{x}^{2}-0.0008 \mathrm{x}^{3}, \mathrm{R}^{2}=0.96, \mathrm{~F}=82.65, P=0.01\right)$, Si $2(\mathrm{y}=36.30-3.82 \mathrm{x}+$ $\left.0.13 \mathrm{x}^{2}-0.0007 \mathrm{x}^{3}, \mathrm{R}^{2}=0.97, \mathrm{~F}=112.33, P=0.01\right)$ and $\mathrm{Si} 3\left(\mathrm{y}=48.81-4.04 \mathrm{x}+0.13 \mathrm{x}^{2}-0.0007 \mathrm{x}^{3}, \mathrm{R}^{2}=0.97, \mathrm{~F}\right.$ $=88.93, P=0.01)$. 

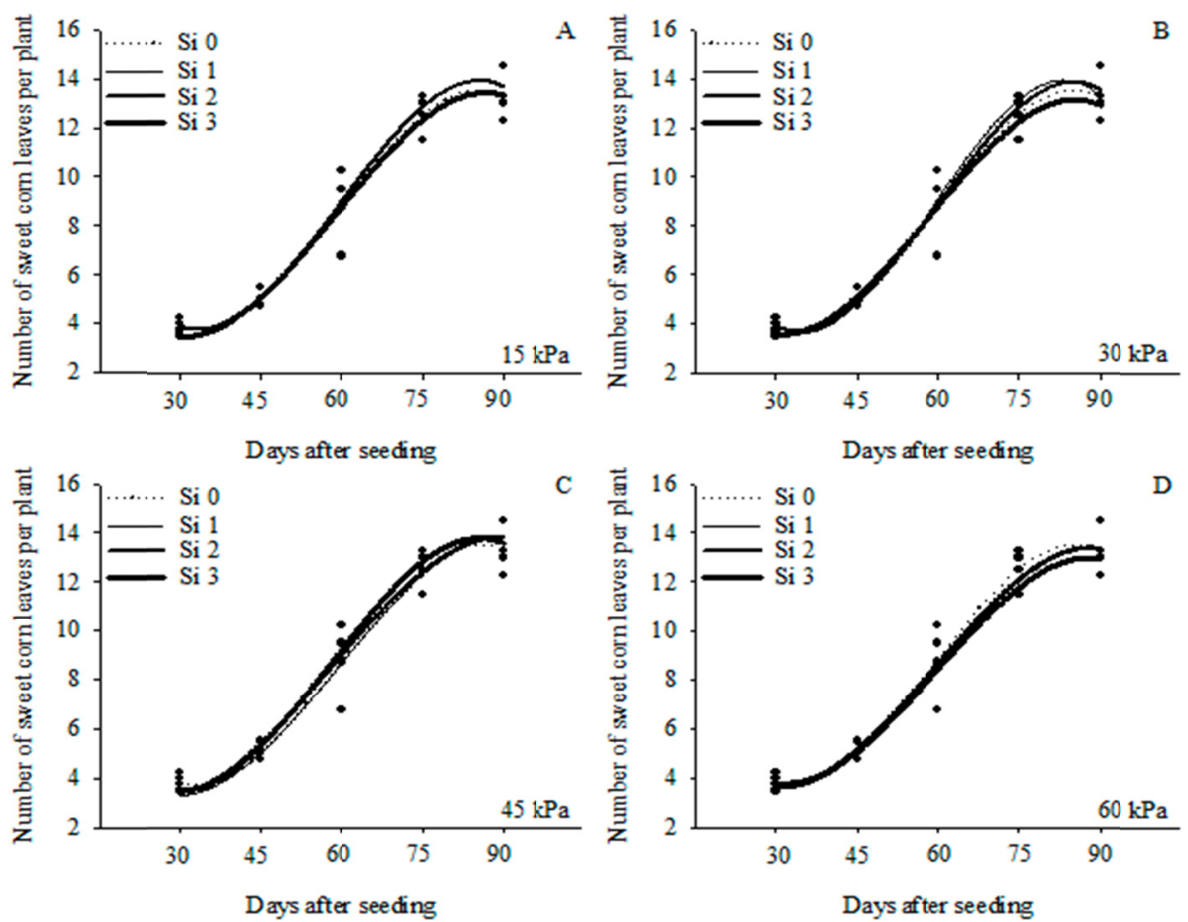

Figure 3. Regression analysis for the number of leaves per plant of sweet corn plants (Zea mays L.), Tropical Plus ${ }^{\circledR}$ hybrid, at five time intervals after germination and submitted to different soil water tensions and potassium silicate doses. Si $0\left(0 \mathrm{~L}_{\text {of }} \mathrm{K}_{2} \mathrm{SiO}_{3} \mathrm{ha}^{-1}\right)$, Si $1\left(6 \mathrm{~L}_{\text {of }} \mathrm{K}_{2} \mathrm{SiO}_{3} \mathrm{ha}^{-1}\right)$, Si $2\left(12 \mathrm{~L}_{\text {of }} \mathrm{K}_{2} \mathrm{SiO}_{3}\right.$ ha $\left.{ }^{-1}\right)$ and $\mathrm{Si} 3(24 \mathrm{~L}$ of $\left.\mathrm{K}_{2} \mathrm{SiO}_{3} \mathrm{ha}^{-1}\right)$. IF Goiano, Urutaí campus, Goiás state, Brazil

Note. Regression data for number of leaves per plant at $15 \mathrm{kPa}$ : $\mathrm{Si} 0\left(\mathrm{y}=20.83-1.18 \mathrm{x}+0.02 \mathrm{x}^{2}-0.0016 \mathrm{x}^{3}, \mathrm{R}^{2}=\right.$ $0.98, \mathrm{~F}=129.95, P=0.01)$, Si $1\left(\mathrm{y}=17.33-0.96 \mathrm{x}+0.02 \mathrm{x}^{2}-0.0011 \mathrm{x}^{3}, \mathrm{R}^{2}=0.98, \mathrm{~F}=214.77, P=0.01\right)$, Si 2 $\left(\mathrm{y}=21.82-1.24 \mathrm{x}+0.02 \mathrm{x}^{2}-0.0016 \mathrm{x}^{3}, \mathrm{R}^{2}=0.99, \mathrm{~F}=812.52, P=0.01\right)$ and $\mathrm{Si} 3\left(\mathrm{y}=16.27-0.93 \mathrm{x}+0.02 \mathrm{x}^{2}-\right.$ $\left.0.0001 \mathrm{x}^{3}, \mathrm{R}^{2}=0.99, \mathrm{~F}=436.52, P=0.01\right)$.

Regression data for number of leaves per plant at $30 \mathrm{kPa}$ : Si $0\left(\mathrm{y}=14.17-0.83 \mathrm{x}+0.01 \mathrm{x}^{2}-0.0001 \mathrm{x}^{3}, \mathrm{R}^{2}=0.99\right.$, $\mathrm{F}=316.79, P=0.01)$, Si $1\left(\mathrm{y}=27.11-1.56 \mathrm{x}+0.03 \mathrm{x}^{2}-0.0002 \mathrm{x}^{3}, \mathrm{R}^{2}=0.99, \mathrm{~F}=478.83, P=0.01\right), \mathrm{Si} 2(\mathrm{y}=$ $\left.23.61-1.34 \mathrm{x}+0.02 \mathrm{x}^{2}-0.0002 \mathrm{x}^{3}, \mathrm{R}^{2}=0.98, \mathrm{~F}=175.81, P=0.01\right)$ and Si $3\left(\mathrm{y}=17.08-0.98 \mathrm{x}+0.02 \mathrm{x}^{2}-\right.$ $\left.0.0001 \mathrm{x}^{3}, \mathrm{R}^{2}=0.99, \mathrm{~F}=405.31, P=0.01\right)$.

Regression data for number of leaves per plant at $45 \mathrm{kPa}$ : Si $0\left(\mathrm{y}=17.08-0.99 \mathrm{x}+0.02 \mathrm{x}^{2}-0.0001 \mathrm{x}^{3}, \mathrm{R}^{2}=0.99\right.$, $\mathrm{F}=307.11, P=0.01)$, Si $1\left(\mathrm{y}=13.81-0.79 \mathrm{x}+0.01 \mathrm{x}^{2}-0.0001 \mathrm{x}^{3}, \mathrm{R}^{2}=0.99, \mathrm{~F}=451.35, P=0.01\right), \mathrm{Si} 2(\mathrm{y}=$ $\left.11.12-0.63 \mathrm{x}+0.01 \mathrm{x}^{2}-0.0002 \mathrm{x}^{3}, \mathrm{R}^{2}=0.98, \mathrm{~F}=226.31, P=0.01\right)$ and $\mathrm{Si} 3\left(\mathrm{y}=16.07-0.94 \mathrm{x}+0.02 \mathrm{x}^{2}\right.$ $\left.0.0001 \mathrm{x}^{3}, \mathrm{R}^{2}=0.99, \mathrm{~F}=434.24, P=0.01\right)$.

Regression data for number of leaves per plant at $60 \mathrm{kPa}$ : Si $0\left(\mathrm{y}=11.95-0.64 \mathrm{x}+0.01 \mathrm{x}^{2}-0.0001 \mathrm{x}^{3}, \mathrm{R}^{2}=0.98\right.$, $\mathrm{F}=139.26, P=0.01)$, Si $1\left(\mathrm{y}=14.60-0.81 \mathrm{x}+0.01 \mathrm{x}^{2}-0.0001 \mathrm{x}^{3}, \mathrm{R}^{2}=0.97, \mathrm{~F}=87.52, P=0.01\right)$, Si $2(\mathrm{y}=$ $\left.15.85-0.87 \mathrm{x}+0.01 \mathrm{x}^{2}-0.0001 \mathrm{x}^{3}, \mathrm{R}^{2}=0.97, \mathrm{~F}=118.53, P=0.01\right)$ and $\mathrm{Si} 3\left(\mathrm{y}=15.18-0.83 \mathrm{x}+0.01 \mathrm{x}^{2}-\right.$ $\left.0.0001 \mathrm{x}^{3}, \mathrm{R}^{2}=0.96, \mathrm{~F}=80.87, P=0.01\right)$.

Interactions between soil-water tensions and potassium silicate doses affected stem diameter (Figure $4 \mathrm{~A})(\mathrm{F}=$ $50.28, \mathrm{df}=36, \mathrm{P}=0.00)$, plant height (Figure $4 \mathrm{~B})(\mathrm{F}=19.44, \mathrm{df}=36, \mathrm{P}=0.01)$ and number of leaves per plant (Figure $4 \mathrm{C})(\mathrm{F}=32.48, \mathrm{df}=36, \mathrm{P}=0.00)$ values when the effect of these factors were evaluated without an age-dependent analysis.

The behavioral response of the sweet corn stem diameter along the soil-water tensions and each potassium silicate dose followed a quadratic regression model (Figure 4A). Stem diameter of sweet corn plants sprayed with potassium silicate was higher at $15 \mathrm{kPa}$ and $60 \mathrm{kPa}$. The intermediate soil-water tensions (30 and $45 \mathrm{kPa})$ had the stem diameter values closer to each other. However, sweet corn plants without potassium silicate applications gave had a smaller stem diameter with all soil-water tensions (Figure 4A). 

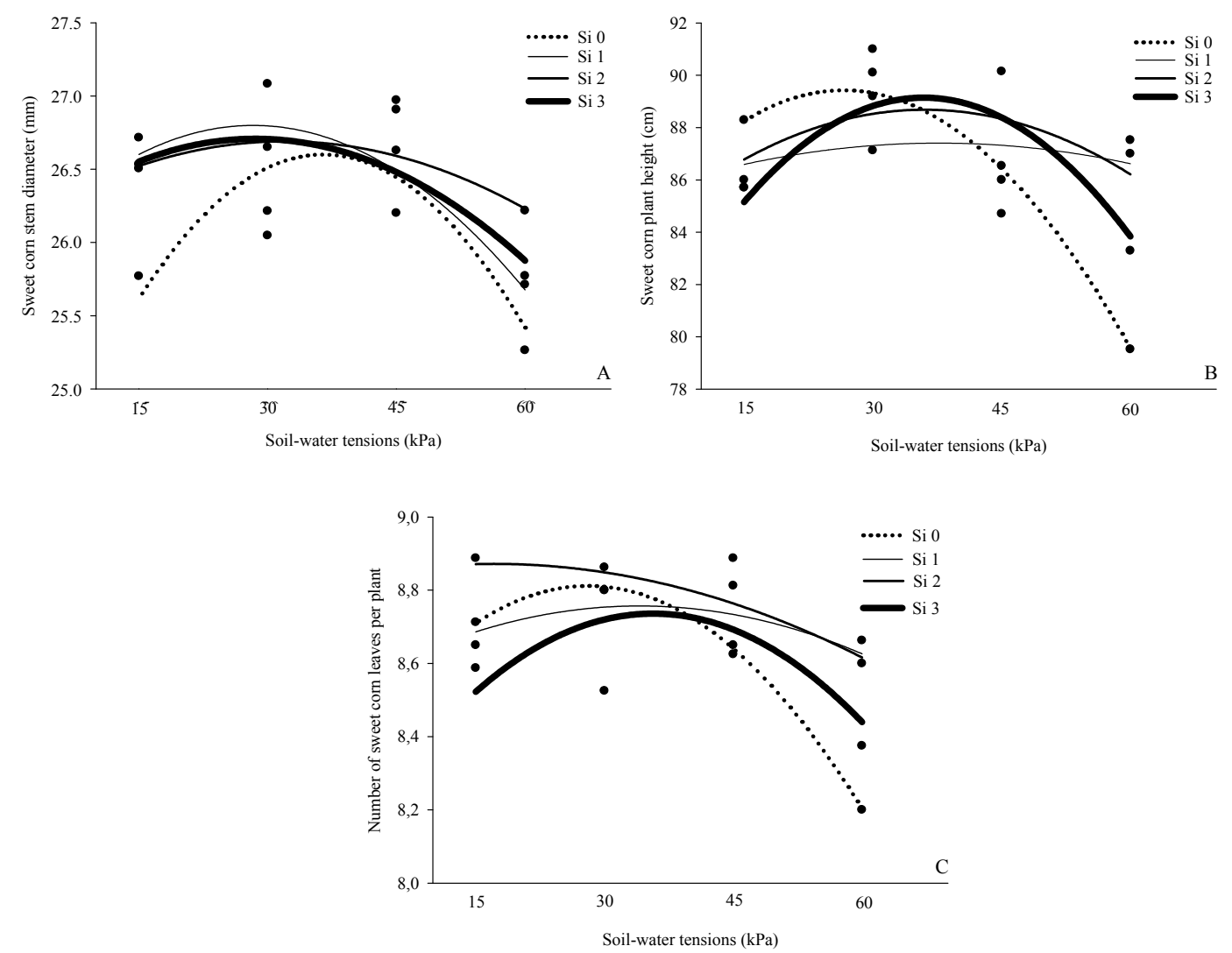

Figure 4. Regression analysis for stem diameter $(\mathrm{mm})(\mathrm{A})$, plant height $(\mathrm{cm})(\mathrm{B})$, and number of leaves per plant (C) of sweet corn (Zea mays L), Tropical Plus ${ }^{\circledR}$ hybrid, under interaction between the factors, soil-water tension $(\mathrm{kPa})$ and potassium silicate doses. Si $0\left(0 \mathrm{~L}_{\text {of }} \mathrm{K}_{2} \mathrm{SiO}_{3} \mathrm{ha}^{-1}\right)$, Si $1\left(6 \mathrm{~L}_{\text {of }} \mathrm{K}_{2} \mathrm{SiO}_{3} \mathrm{ha}^{-1}\right)$, Si $2\left(12 \mathrm{~L} \mathrm{of}_{2} \mathrm{SiO}_{3} \mathrm{ha}^{-1}\right)$ and $\mathrm{Si} 3$ (24 $\mathrm{L}_{\text {of }} \mathrm{K}_{2} \mathrm{SiO}_{3} \mathrm{ha}^{-1}$ ). IF Goiano, Urutaí campus, Goiás state, Brazil

Note. Regression data for stem diameter: $\mathrm{Si} 0\left(\mathrm{y}=0.23+0.15 \mathrm{x}-0.21 \mathrm{x}^{2}, \mathrm{R}^{2}=0.86, \mathrm{~F}=300.09, P=0.04\right)$, Si 1 $\left(\mathrm{y}=0.25+0.63 \mathrm{x}-0,11 \mathrm{x}^{2}, \mathrm{R}^{2}=0.80, \mathrm{~F}=199.05, P=0.04\right), \mathrm{Si} 2\left(\mathrm{y}=0.26+0.37 \mathrm{x}-0.58 \mathrm{x}^{2}, \mathrm{R}^{2}=0.92, \mathrm{~F}=\right.$ $189.00, P=0.03)$ and $\operatorname{Si} 3\left(\mathrm{y}=0.26+0.48 \mathrm{x}-0.84 \mathrm{x}^{2}, \mathrm{R}^{2}=0.72, \mathrm{~F}=370.08, P=0.04\right)$.

Regression data for plant height: $\mathrm{Si} 0\left(\mathrm{y}=0.83+0.46 \mathrm{x}-0.88 \mathrm{x}^{2}, \mathrm{R}^{2}=0.99, \mathrm{~F}=913.12, P=0.02\right), \mathrm{Si} 1(\mathrm{y}=0.85$ $\left.+0.13 \mathrm{x}-0,17 \mathrm{x}^{2}, \mathrm{R}^{2}=0.81, \mathrm{~F}=200.050, P=0.00\right)$, Si $2\left(\mathrm{y}=0.83+0.32 \mathrm{x}-0.44 \mathrm{x}^{2}, \mathrm{R}^{2}=0.84, \mathrm{~F}=160.01, P=\right.$ $0.04)$ and $\operatorname{Si} 3\left(\mathrm{y}=0.77+0.66 \mathrm{x}-0.91 \mathrm{x}^{2}, \mathrm{R}^{2}=0.73, \mathrm{~F}=136.12, P=0.04\right)$.

Regression data for number of leaves per plant: $\mathrm{Si} 0\left(\mathrm{y}=0.83+0.33 \mathrm{x}-0.59 \mathrm{x}^{2}, \mathrm{R}^{2}=0.99, \mathrm{~F}=549.40, P=0.03\right)$, Si $1\left(\mathrm{y}=0.77+0.38 \mathrm{x}-0,34 \mathrm{x}^{2}, \mathrm{R}^{2}=0.83, \mathrm{~F}=320.20, P=0.00\right), \mathrm{Si} 2\left(\mathrm{y}=0.88+0.47 \mathrm{x}-0.13 \mathrm{x}^{2}, \mathrm{R}^{2}=0.88, \mathrm{~F}=\right.$ $379.14, P=0.03)$ and Si $3\left(\mathrm{y}=0.81+0.35 \mathrm{x}-0.50 \mathrm{x}^{2}, \mathrm{R}^{2}=0.82, \mathrm{~F}=320.02, P=0.02\right)$.

Plant height showed a decreasing growth as soil-water tension increased, regardless of potassium silicate doses. However, the application of potassium silicate doses reduced this drop in sweet corn plants compared to the Si 0 $\left(0 \mathrm{~L}\right.$ of $\mathrm{K}_{2} \mathrm{SiO}_{3} \mathrm{ha}^{-1}$ ) dose. Plants sweet corn had the highest drop in height with $60 \mathrm{kPa}$ tension without potassium silicate spraying (Figure 4B).

Sweet corn plants had the lowest number of leaves with $60 \mathrm{kPa}$, regardless of the potassium silicate use. Conversely, the $15 \mathrm{kPa}$ tension originated plants with greater number of leaves. The presence of potassium silicate reduced the drop of sweet corn plant growth parameters compared with its absence. Plants submitted to foliar potassium silicate application had a lower reduction in the number of leaves per plant as water stress increased. Plants without potassium silicate application showed a reduction in the number of leaves with $60 \mathrm{kPa}$ (Figure 4C).

The interaction between the two independent factors evaluated was not observed for the root length of sweet corn plants $(\mathrm{F}=1.38, \mathrm{df}=36, \mathrm{P}=0.23)$. These parameters differed only between soil-water tensions $(\mathrm{F}=11.48$, $\mathrm{df}=36, \mathrm{P}=0.00)$ (Figure 5). Root length was longer at $60 \mathrm{kPa}(30.37 \pm 0.94 \mathrm{~cm})$ than at $15 \mathrm{kPa}(26.93 \pm 1.08 \mathrm{~cm})$, $30 \mathrm{KPa}(27.00 \pm 0.80 \mathrm{~cm})$ and $45 \mathrm{kPa}(26.25 \pm 0.78 \mathrm{~cm})$ (Figure 5). 


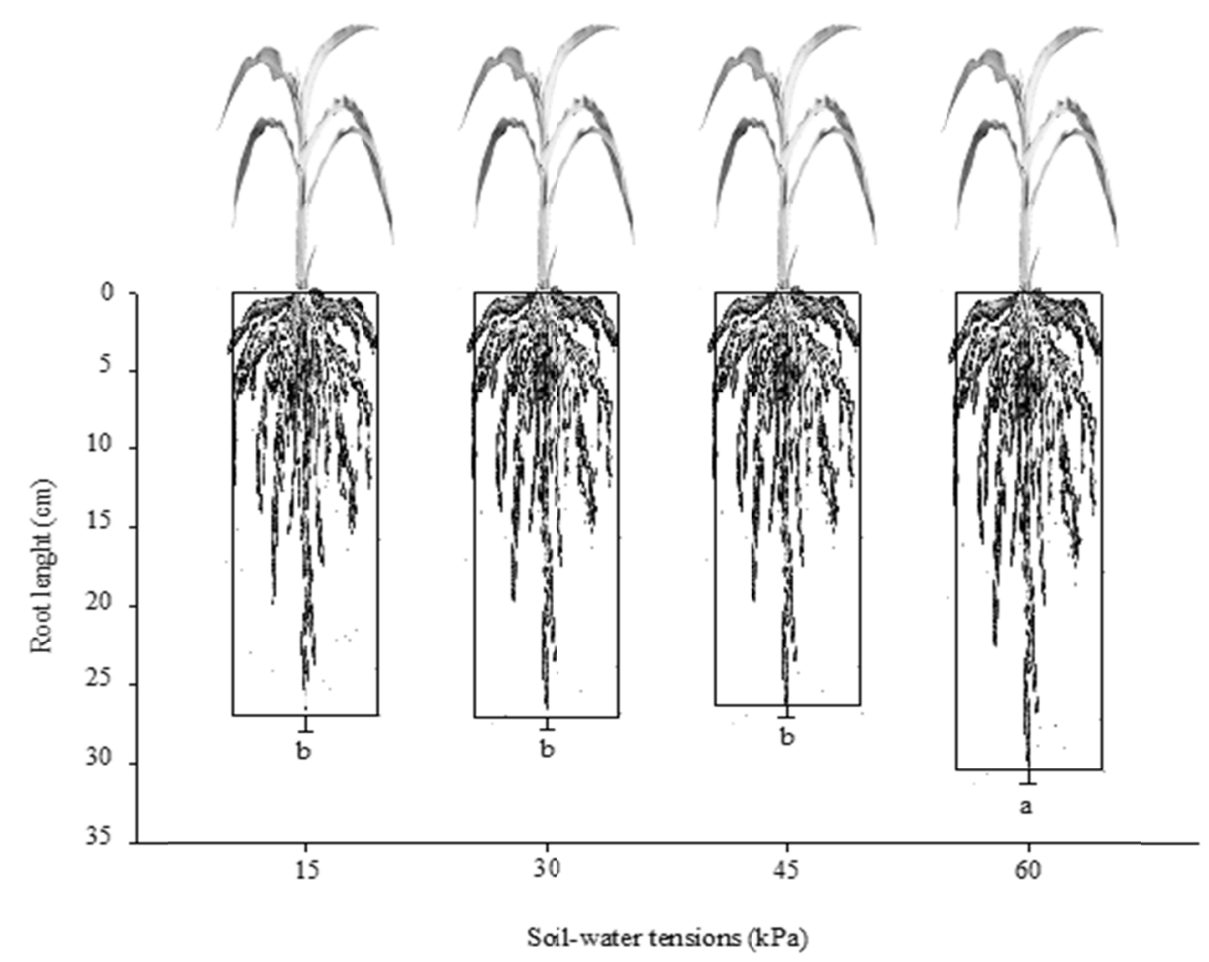

Figure 5. Root length $(\mathrm{cm})\left(\right.$ mean $\pm \mathrm{EP}^{1}$ ) of sweet corn (Zea mays L.), Tropical Plus ${ }^{\circledR}$ hybrid, with different soil-water tensions $(\mathrm{kPa})$. IF Goiano, Urutaí campus, Goiás state, Brazil. ${ }^{1}$ Means followed by the same letter do not differ at the $5 \%$ probability level by Tukey test. Corn plants pictures are merely illustrative, not corresponding to their real dimensions, and were adapted from www.behance.net, with credits of Jeffrey Marshall

\section{Discussion}

The higher plasticity of sweet corn stem diameter to water stress, compared to plant height and number of leaves per plant, has been previously reported (Brito et al., 2013). Corn stem store carbohydrates (Slewinski 2012) and exogenous silicate sources may, indirectly, increase carbohydrate production in Poaceae plants due to a better photosynthetic efficiency promoted (Xie et al., 2014). This may explain wider stem diameters with potassium silicate, especially, when a stress condition was imposed (45 to $60 \mathrm{kPa}$ ). The cubic regression model for stem diameter may indicate that carbohydrate reserve varies with plant phenological stage. Carbohydrates accumulated during the vegetative period are sent to reproductive organs at the beginning of the reproductive period which retards stem diameter growth (Russo et al., 2004). This justifies different stem growth responses shown by regression curves between stem diameter, plant height and number of leaves per plant. Translocation of carbohydrates to reproductive organs prevented stem diameter growth of sweet corn plants during this phenology stage.

Potassium silicate avoided decrease on stem diameter, plant height and number of leaves per sweet corn plants under water stress. Sweet corn plants, normally, have a sharp decrease in growth parameters under water stress (Anjum et al., 2011). Leaf stomata tend to close to reduce excessive transpiration causing low photosynthesis and photoassimilate production, which impairs plant growth. Si accumulation in the transpiration organs forms a double silica layer with a decrease in stomata opening reduce leaf transpiration and limiting water losses without affecting plant growth (Meena et al., 2014). Potassium silicate sprayed on sweet corn plants acted as a resistance elicitor for stem diameter, plant height and number of leaves per corn plant under abiotic stress as also observed with wheat plants (Gong et al., 2005).

The lacking effect of potassium silicate (isolated or under interaction) with soil-water tensions on root length agrees with that reported for this parameter biomass with silicon, and differences in enzyme concentrations was also related to oxidative stress due to exposure to the heavy metal Antimony (Sb) (Vaculikova et al., 2015). This proves that the effect of $\mathrm{Si}$ on plants may be related to morphometric changes and also as a stimulus to biochemical defenses. Corn plants had longer branched roots and greater fresh and dry biomass under stress 
conditions through exposure to the heavy metal Cadmium (Cd) with Si in nutrient solution (Vaculík et al., 2012). This discrepancy in responses for root structure in corn plants with $\mathrm{Si}$ and poisoning by heavy metals, appears to be related to the species and cultivar. This was shown by the different responses in the root morphometry of corn plants between hybrids treated simultaneously with Si and Cd (Kuliková \& Lux, 2010).

Corn strains tolerant to water scarcity with long roots ( $\mathrm{Li}$ et al., 2015) demonstrate ability to obtain water from deeper soil layers under high water stress, such as those with $60 \mathrm{kPa}$. Root growth of agricultural plants tends to be lower in soil with high soil-water tension values due to the combination of water stress (lack of water for plant growth) and mechanical impedance (resistance to soil penetration caused by tension between particles) (Bengough et al., 2011). The ability of extracting water from the soil seems to be species-specific under water stress (Schoo et al., 2016). Lateral and thinner corn roots $(<2 \mathrm{~mm}$ diameter) are responsible for high water and mineral ions (Eissenstat et al., 2000) as well as Si uptake from the soil (Gahhoonia and Nielsen 2004, Mitani et al., 2009). The most abundant and central roots support the plants with low water and nutrient absorption (Gahhoonia and Nielsen 2004) and water stress should be more evident on finer roots. The root length of sweet corn roots with greater vertical depth (probably those with $>2.0 \mathrm{~mm}$ diameter) did not vary with its thickness. The results agree with those observed, under water stress conditions, with the greatest vertical expansion of the corn root system to absorb water from deeper layers in the soil (Hund et al., 2009).

\section{Conclusions}

The role of silicon as an additional input can be valuable in agricultural regions with frequent dry spells, such as those in the Brazilian Cerrado Savanna biome. Sweet corn stem diameter, plant height and number of leaves per plant did not decrease under water stress, when sprayed with potassium silicate. These developmental parameters, mainly stem diameter, showed a close relationship with Si under water stress. Root length had higher values with $60 \mathrm{kPa}$ soil-water tension, but no apparent silicon-dependent effect. The protective role of silicon reducing negative impacts of water stress on sweet corn developmental traits was confirmed.

\section{Acknowledgements}

To CNPq and FAPEG for the granting of financial assistance. To Programa de Pós-Graduação Profissional em Bioenergia e Grãos. To Conservas Oderich SA. And, finally, to Instituto Federal Goiano for the structural support for the execution of this work.

\section{References}

Anjum, S. A., Xie, X. Y., Wang, L. C., Saleem, M. F., Man, C., \& Lei, W. (2011). Morphological, physiological and biochemical responses of plants to drought stress. African Journal of Agricultural Research, 6, 2026-2032. https://doi.org/10.5897/AJAR10.027

Barnaby, J. Y., Kim, M., Bauchan, G., Bunce, J., Reddy, V., \& Sicher, R. C. (2013). Drought responses of foliar metabolites in three maize hybrids differing in water stress tolerance. PLoS ONE, 8, e77145. https://doi.org/10.1371/journal.pone.0077145

Bengough, A. G., McKenzie, B. M., Hallett, P. D., \& Valentine, T. A. (2011). Root elongation, water stress, and mechanical impedance: a review of limiting stresses and beneficial root tip traits. Journal of Experimental Botany, 62, 59-68. https://doi.org/10.1093/jxb/erq350

Borssoi, A. L., Vilas Boas, M. A., Reisdörfer, M., Hernández, R. H., \& Follador, F. A. C. (2012). Water application uniformity and fertigation in a dripping irrigation set. Engenharia Agrícola, 32, 718-726. https://doi.org/10.1590/S0100-69162012000400011

Brito, M. E. B., Filho, G. D. A., Wanderley, J. A. C., Melo, A. S., Costa, F. B., \& Ferreira, M. G. P. (2013). Crescimento, fisiologia e produção do milho doce sob estresse hídrico. Bioscience Journal, 29, 1244-1254.

Camargo, M. S., Rocha, G., \& Korndorfer, G. H. (2013). Silicate fertilization of tropical soils: silicon availability and recovery index of sugarcane. Revista Brasileira de Ciência do Solo, 37, 1267-1275. https://doi.org/ $10.1590 / \mathrm{S} 0100-06832013000500016$

Doto, V. C., Yacouba, H., Niang, D., Lahmar, R., \& Agbossou, E. K. (2015). Mitigation effect of dry spells in Sahelian rainfed agriculture: Case study of supplemental irrigation in Burkina Faso. African Journal of Agricultural Research, 10, 1863-1873. https://doi.org/10.5897/AJAR2015.9639

Eissenstat, D. M., Wells, C. E., \& Yanai, R. D. (2000). Building roots in a changing environment: Implications for root longevity. New Phytologist, 147, 33-42. https://doi.org/10.1046/j.1469-8137.2000.00686.x 
Embrapa (Empresa Brasileira de Pesquisa Agropecuária). (1999). Sistema brasileiro de classificação de solos. SPI/CNPS, Brasília, DF, Brazil.

Gahoonia, T. S., \& Nielsen, N. E. (2004). Root traits as tools for creating phosphorus efficient crop varieties. Plant and Soil, 260, 47-57. https://doi.org/24129008

Gong, H., Zhu, X., Chen, K., Wang, S., \& Zhang, C. (2005). Silicon alleviates oxidative damage of wheat plants in pots under drought. Plant Science, 169, 313-321. https://doi.org/10.1016/j.plantsci.2005.02.023

Guntzer, F., Keller, C., \& Meunier, J. D. (2012). Benefits of plant silicon for crops: a review. Agronomy for Sustainable Development, 32, 201-213. https://doi.org/10.1007/s13593-011-0039-8

Heinemann, A. B., Andrade, C. L. T., Gomide, R. L., Amorim, A. O., \& Paz, R. L. (2009). Padrões de deficiência hídrica para a cultura de milho (safra normal e safrinha) no estado de Goiás e suas consequências para o melhoramento genético. Ciência e Agrotecnologia, 33, 1026-1033.

Hund, A., Ruta, N., \& Liedgens, M. (2009). Rooting depth and water efficiency of tropical maize inbred lines, differing in drought tolerance. Plant and Soil, 318, 311-325. https://doi.org/10.1007/s11104-008-9843-6

Kuliková, Z. L., \& Lux, A. (2010). Silicon influence on maize, Zea mays L., hybrids exposed to cadmium treatment. Bulletin of Environmental Contamination and Toxicology, 85, 243-250. https://doi.org/10.1007/ s00128-010-0046-5

Li, R., Zeng, Y., Xu, J., Wang, Q., Wu, F., Cao, M., Lan, H., Liu, Y., \& Lu, Y. (2015). Genetic variation for maize root architecture in response to drought stress at the seedling stage. Breeding Science, 65, 298-307. https://doi.org/10.1270/jsbbs.65.298

Li, W., Zhang, P., Ye, J., Li, L., \& Baker, P. A. (2011). Impact of two different types of El Niño events on the Amazon climate and ecosystem productivity. Journal of Plant Ecology, 4, 91-99. https://doi.org/ 10.1093/jpe/rtq039

Maghsoudi, K., Emam, Y., \& Pessarakli, M. (2016). Effect of silicon on photosynthetic gas exchange, photosynthetic pigments, cell membrane stability and relative water content of different wheat cultivars under drought stress conditions. Journal of Plant Nutrition, 39, 1001-1015. https://doi.org/10.1080/ 01904167.2015 .1109108

Malčovská, S. M., Dučaiová, Z., Maslaňáková, I., \& Bačkor, M. (2014). Effect of silicon on growth, photosynthesis, oxidative status and phenolic compounds of Maize (Zea mays L.) grown in cadmium excess. Water, Air, \& Soil Pollution, 225, 2-11. https://doi.org/10.1007/s11270-014-2056-0

Meena, V. D., Dotaniya, M. L., Coumar, V., Rajendiran, S., Kundu, S., \& Rao, A. S. (2014). A case for silicon fertilization to improve crop yields in tropical soils. Proceedings of the National Academy of Sciences, India Section B: Biological Sciences, 84, 505-518. https://doi.org/10.1007/s40011-013-0270-y

Mitani, N., Yamaji, N., \& Ma, J. F. (2009). Identification of Maize silicon influx transporters. Plant and Cell Physiology, 50, 5-12. https://doi.org/10.1093/pcp/pcn110

Nissan, H., Blum, S., Shimoni, E., \& Elbaum, R. (2015). Characterization of silicon accumulation in Maize cell suspension cultures. Silicon, 1-7. https://doi.org/10.1007/s12633-015-9347-y

Ribeiro Júnior, J. I., \& Melo, A. L. P. (2008). Guia prático para utilização do SAEG. Editora UFV. Viçosa, Minas Gerais, Brazil.

Russo, V. M., Collins, J. K., \& Perkins, P. (2004). Carbohydrate distribution in a sweet maize with the sugar enhanced endosperm genotype. Cereal Research Communications, 32, 347-353. https://doi.org/23787143

Salton, J. C., Mercante, F. M., Tomazi, M., Zanatta, J. A., Concenço, G., Silva, W. M., \& Retore, M. (2014). Integrated crop-livestock system in tropical Brazil: Toward a sustainable production system. Agriculture, Ecosystems \& Environment, 190, 70-79. https://doi.org/10.1016/j.agee.2013.09.023

Schoo, B., Schroetter, S., Kage, H., \& Schittenhelm, S. (2016). Root traits of cup plant, maize and lucerne grass grown under different soil and soil moisture conditions. Journal of Agronomy and Crop Science, 203, 345-359. https://doi.org/10.1111/jac.12194

Slewinski, T. L. (2012). Non-structural carbohydrate partitioning in grass stems: A target to increase yield stability, stress tolerance, and biofuel production. Journal of Experimental Botany, 63, 4647-4670. https://doi.org/10.1093/jxb/ers 124 
Tahir, M., Hassan, A. U., Zahir, Z. A., \& Rehman, K. U. (2012). Modeling water retention capacity and hydraulic properties of a manure-amended loam soil and its effect on wheat and maize yield. International Journal of Agriculture \& Biology, 14, 492-498.

Trani, P. E., Tiveli, S. W., \& Carrijo, O. A. (2011). Fertirrigação em hortaliças (2nd ed.). Boletim Técnico IAC. Campinas, São Paulo, Brazil.

Vaculík, M., Landberg, T., Greger, M., Luxová, M., Stoláriková, M., \& Lux, A. (2012). Silicon modifies root anatomy, and uptake and subcellular distribution of cadmium in young maize plants. Annals of Botany, 110, 433-443. https://doi.org/10.1093/aob/mcs039

Vaculíkováa, M., Vaculíkb, M., Šimkováa, L., Fialováa, I., Kochanováa, Z., Sedlákováa, B., \& Luxováa, M. (2014). Influence of silicon on maize roots exposed to antimony-Growth and antioxidative response. Plant Physiology and Biochemistry, 83, 279-284. https://doi.org/10.1016/j.plaphy.2014.08.014

Van Genuchten, M.T. (1980). A closed-form equation for predicting the hydraulic conductivity of unsaturated soils. Soil Science Society of America Journal, 44, 892-898. https://doi.org/10.2136/sssaj1980.0361599 $5004400050002 x$

Xie, Z., Song, F., Xu, H., Shao, H., \& Son, R. (2014). Effects of silicon on photosynthetic characteristics of Maize (Zea mays L.) on alluvial soil. The Scientific World Journal. https://doi.org/10.1155/2014/718716

Zhu, Y., \& Gong H. (2014). Beneficial effects of silicon on salt and drought tolerance in plants. Agronomy for Sustainable Development, 34, 455-472. https://doi.org/10.1007/s13593-013-0194-1

\section{Copyrights}

Copyright for this article is retained by the author(s), with first publication rights granted to the journal.

This is an open-access article distributed under the terms and conditions of the Creative Commons Attribution license (http://creativecommons.org/licenses/by/4.0/). 